\title{
The «Museum and Inclusive Fashion» Project. A Design for All Experience at the Balearic School of Art and Design
}

\author{
Maria del Pilar ROVIRA ${ }^{\mathrm{a}, 1}$, Maria del Mar VILALTA ${ }^{\mathrm{a}}$, Francisca M. TORRENS ${ }^{\mathrm{a}}$, \\ Maria F. ABANDO ${ }^{\mathrm{a}}$, Irene MESTRE ${ }^{\mathrm{a}}$ and Margalida CANET ${ }^{\mathrm{a}}$ \\ a Escola d'Art i Superior de Disseny de les Illes Balears, Spain
}

\begin{abstract}
International regulations about Accessibility and Design for All are clear. They provide two guidelines to ensure equality, autonomy, and non-discrimination, such as Reasonable Accommodation and Universal Design (or Design for All). Reasonable Accommodation leads to Adapted Fashion, which adjusts clothing to the body (average clothes for the average consumer). Universal Design leads to Inclusive Fashion, which creates clothes for everybody even if you have a body issue. Design for All (or Universal Design) implies projecting from the beginning to the end of the design process based on inclusion. In this context, the MuseumFoundation Juan March in Palma was the starting point to conceive, develop and communicate a collaborative and transdisciplinary design project; it was designed under the principle of Universal Design. This transdisciplinary co-design project took place during the first semester of the 2019-2020 academic year with a thirdyear BA in Fashion Design students. They designed an inclusive ready-to-wear fashion micro-collection, which focused on sensitizing BA in Fashion Design students, promoting a change of attitude, and fostering a better understanding of the challenges clothing design process. Students were invited to complete two online questionnaires to collect data on the project. The first survey was used to assess alumni's perception of acquisition, development, and/or consolidation of key competences in participating students and control groups. The second survey was used to assess alumni's activity on the project among participating students. This project was aimed at sensitizing BA in Fashion Design students, promoting a change of attitude, and a better understanding of the challenges clothing design process. After visiting the museum, getting inspired by their artists and their works of art, creating a mood board, and drawing the first sketches, two groups were created to develop an inclusive, ready-to-wear fashion micro-collection. Each collection focused on a different users' profile: one group worked with a model with achondroplasia (woman), and the other group worked with two wheelchair models (man, woman). Despite the mixed results, the main objectives of the project were reached. As members of a school community, students must learn about other realities that differ from their everyday environment. As members of a school of design, students must be aware of an important prospective market niche and expand their fields of action that must include Design for All. In any case, human diversity is the key concept to approach user-centred design in the twenty-first century. The «Museum and Inclusive Fashion» project was part of an ongoing academic research project funded by the Balearic Government (2017-2020). This article reflects the views only of the authors, and the Balearic Government cannot be held responsible for any use which may be made of the information contained therein.
\end{abstract}

Keywords. Inclusive Fashion, Project-Based Learning, Design for All

\footnotetext{
${ }^{1}$ Maria del Pilar ROVIRA SERRANO, GRID-EASDIB GOIB, Escola d'Art I Superior de Disseny de les Illes Balears, c/ Institut Balear 5, 07012 Palma, Mallorca, Illes Balears, Spain; E-mail: grid@escoladisseny.com.
} 


\section{Introduction}

International regulations about Accessibility and Design for All are clear. They provide two guidelines to ensure equality, autonomy, and non-discrimination, such as Reasonable Accommodation and Universal Design (or Design for All). Article 2 of the UN Convention on the Rights of Persons with Disabilities, adopted on 2006, 13th December [1], defines Reasonable Accommodation and Universal Design (or Design for All).

On the one hand, a Reasonable Accommodation means a necessary and appropriate modification and adjustments not imposing a disproportionate or undue burden, where needed in a particular case, to ensure to persons with disabilities the enjoyment or exercise on an equal basis with others of all human rights and fundamental freedoms.

On the other hand, Universal Design means designing products, environments, programs, and services to be usable by all people, to the greatest extent possible, without the need for adaptation or specialized design. It shall not exclude assistive devices for particular groups of persons with disabilities where this is needed.

Reasonable Accommodation leads to Adapted Fashion (Orthopaedic Fashion, in the opinion of Rut Turró, from Moving for a Good Mood [2]), which adjusts clothing to the body (average clothes for the average consumer). However, Universal Design leads to Inclusive Fashion, which creates clothes for everybody even if you have a body issue.

It is important to mention that Reasonable Accommodation implies adapting (patching) the product once the design process is over. This solution does not imply an economic profit because the same work is done twice due to lack of planning.

On the other hand, Universal Design leads to inclusive fashion. It implies projecting from the beginning to the end of the design process based on inclusion. This solution implies an economic profit because the same product is offered to more than one unique niche market. In any case, total accessibility does not exist, as it is a utopia.

In any case, Reasonable Adjustments and Universal Design's main final objective are to promote autonomy and users' independence since people have different abilities.

\section{Background}

In this context, the Museum-Foundation Juan March in Palma, their artists, and their works of art were the starting point for the «Museum and Inclusive Fashion» project to conceive, develop and communicate a collaborative and trans-disciplinary design project; it was designed under the principle of Universal Design.

The Museum-Foundation Juan March in Palma is based in a grand 17th-century building. It showcases works of art from 20th-century Spanish artists. It hosts a permanent collection of seventy representative examples of the innovative artistic movements of the mid-twentieth century. It preserves works of art by fifty-two Spanish vanguard artists, such as Pablo Picasso, Joan Miró, Juan Gris, or Salvador Dalí. [3].

It was a design project because students followed the design methodology to develop the activity: 1/ theoretical introduction; 2/ design problem approach (individual, at first; in groups, later on), and collective brainstorming; 3/ realization from the proposed material; 4/ exhibition; and 5/ assessment.

It was a trans-disciplinary project because students used all their knowledge acquired while studying BA in Fashion Design: artistic drawing, illustration, technical drawing, pattern making, sewing, styling, photography, video, management... 
It was a collaborative project because the school involved students and users from ASPAYM Illes Balears and PREDIF Illes Balears. Other stakeholders were also involved, such as the Museum-Foundation Juan March in Palma, Ribes \& Casals, and Territorial Delegation ONCE Illes Balears.

This transdisciplinary co-design project took place during the first semester of the 2019-2020 academic year with a third-year BA in Fashion Design students. They designed an inclusive ready-to-wear fashion micro-collection, which focused on sensitizing BA in Fashion Design students, promoting a change of attitude, and fostering a better understanding of the challenges clothing design process.

\section{Research questions}

This article is aimed at answering six research questions:

- Research question \#1: Is there any difference in students' perception about acquiring, developing, and/or consolidating key professional competences, at the beginning and the end of the activity?

- Research question \#2: Is there any difference in students' perception between the participating group and the control group?

- Research question \#3: Do participating students identify professional profile areas involved in the project?

- Research question \#4: Do participating students identify key professional competences selected by researchers?

- Research question \#5: Do participating students acquire, develop, and/or consolidate competences related to BA in Fashion Design studies?

- Research question \#6: Do participating students achieve learning outcomes selected by researchers?

\section{Method}

Before starting the activity, students received a briefing with detailed information about the project: abstract, partners, references in art, references in Inclusive Fashion, professional profile areas involved (the main ones and the secondary ones), key competences to be acquired, developed, and/or consolidated (the main ones, the secondary ones, and the tertiary ones), Fashion Design competences to be acquired, developed, and/or consolidated, learning outcomes to be achieved, schedule, assessment criteria.

Then, students were invited to complete two online questionnaires to collect data on the project. The first online survey was used to assess alumni's perception of acquisition, development, and/or consolidation of key competences in participating students (divided into two groups), and compare them with non-participating students (control group). It presented 33 questions distributed in three parts. Participating and non-participating students filled in the online survey twice, at the beginning and the end of the activity.

- Students' background (four items): first surname, second surname, name, and email address.

- Key professional competences to be assessed (22 competences), formulated by researchers (scored from 0 to 10) [4]. 
- Students' profile (seven items): gender, specialty, year of study, date of birth, number of years, residence, and personal situation.

The second online survey was used to assess alumni's activity on the project among participating students. It presented 27 items distributed in seven parts. Participating students filled it in at the end of the activity.

- Students' background (six items): telephone number, school email address, personal email address, first surname, second surname, and name.

- Fashion Design project, including three items: title, group participants, and abstract of the project.

- Professional profile, one closed question that included 16 different areas stated by Spanish regulations.

- Competences to be acquired, including one closed question about 22 key professional competences formulated by researchers [4], and another closed question about nine competences related to Fashion Design studies stated by Spanish regulations (fail, pass, remarkable, outstanding).

- Learning outcomes to be achieved, one closed question that included seven items formulated by researchers (fail, pass, remarkable, outstanding).

- Personal experience, including nine open questions related to the learning experience: three main learnings, the importance of learning for the student, the best of the experience, the worst of the experience, a micro-story about the personal museum experience, a micro-story about the Inclusive Fashion microcollection experience and a micro-story about the working in group experience.

- Assessment, including five mixed questions, such as, «How relevant was the activity to your future academic pursuits» (Scored from 0 to 10), «How relevant was the activity to your future career paths» (Scored from 0 to 10), «Overall satisfaction with the activity» (Scored from 0 to 10), «Would you repeat the activity? (Closed question: yes, no), and «Any Suggestion».

In September 2019, fourteen students (eight subjects in the participating groups and six subjects in the control group) filled in the first questionnaire. In January 2020, a total of twelve students (eight subjects in the participating groups and four subjects in the control group) filled in the first questionnaire again (as two people had left the course); and a total of eight students (all participants) filled in the second questionnaire.

\section{Results}

This project was aimed at sensitizing BA in Fashion Design students, promoting a change of attitude, and a better understanding of the challenges clothing design process. After visiting the museum, getting inspired by their artists and their works of art, creating a mood board, and drawing the first sketches, two groups were created to develop an inclusive, ready-to-wear fashion micro-collection. Each collection focused on a different users' profile: one group worked with a model with achondroplasia (woman), and the other group worked with two wheelchair models (man, woman). Despite the mixed results, the main objectives of the project were reached.

The five students from Group \#1 (Figure 1) worked with a model with achondroplasia (woman).

The three students from Group \#2 (Figure 2) worked with two wheelchair models (man, woman). 


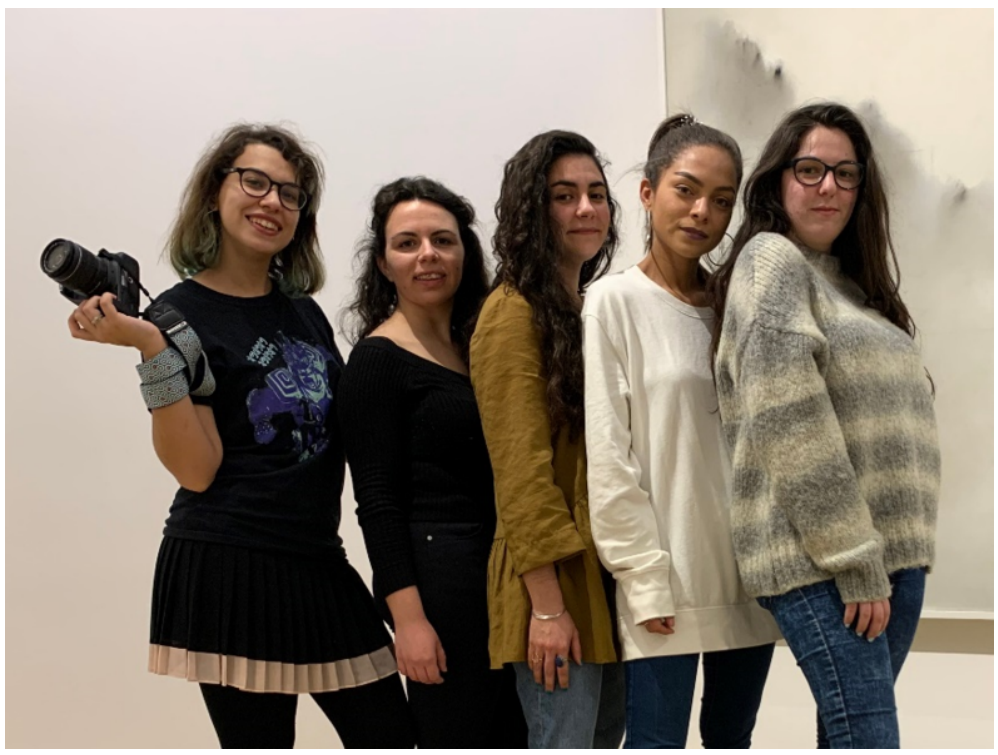

Figure 1. Group \#1, from left to right, Selene Cifre, Andrea Mollá Anabel Collado, Daniela Cardona and Laia Sastre.

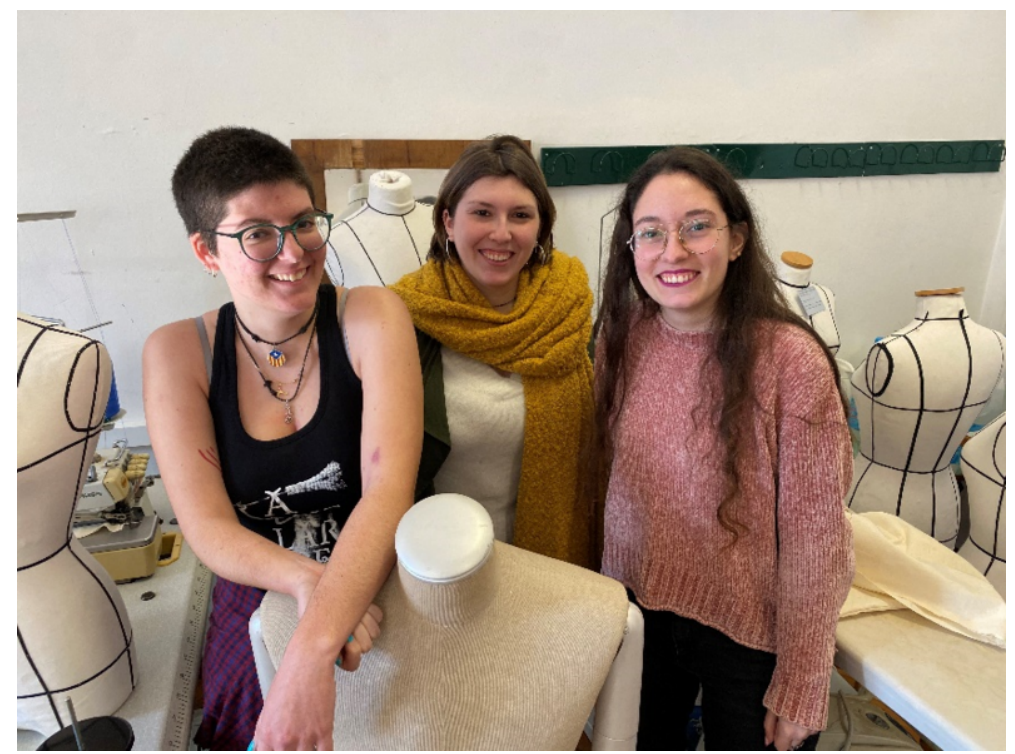

Figure 2. Group \#2, from left to right, Xesca Fernandez De Heredia, Lis Nadia Mir and Marta Durán.

Group \#1 designed Blue View (Figure 3), a ready-to-wear Inclusive Fashion microcollection, especially aimed at women with achondroplasia. It inspired by three works of art that are preserved in the Museum-Foundation Juan March in Palma: The View XXVI (Fernando Zóbel, 1974), Tríptico azul (Juan Suárez, 1981), and Without Title (Miguel Ángel Campano, 1979). Blue View sought the comfort of the users, without forgetting the current aesthetics and fashion trends, which are reflected by the colours and fabrics chosen. 


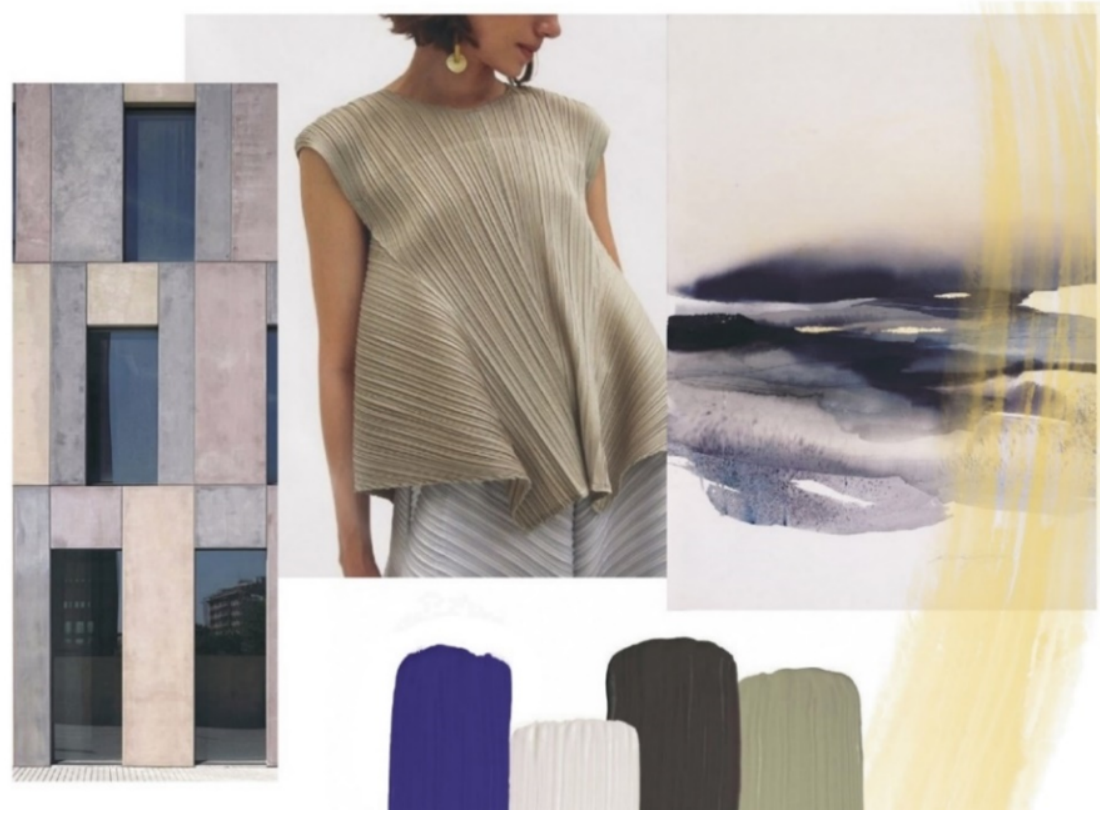

Figure 3. Blue View moodboard panel.

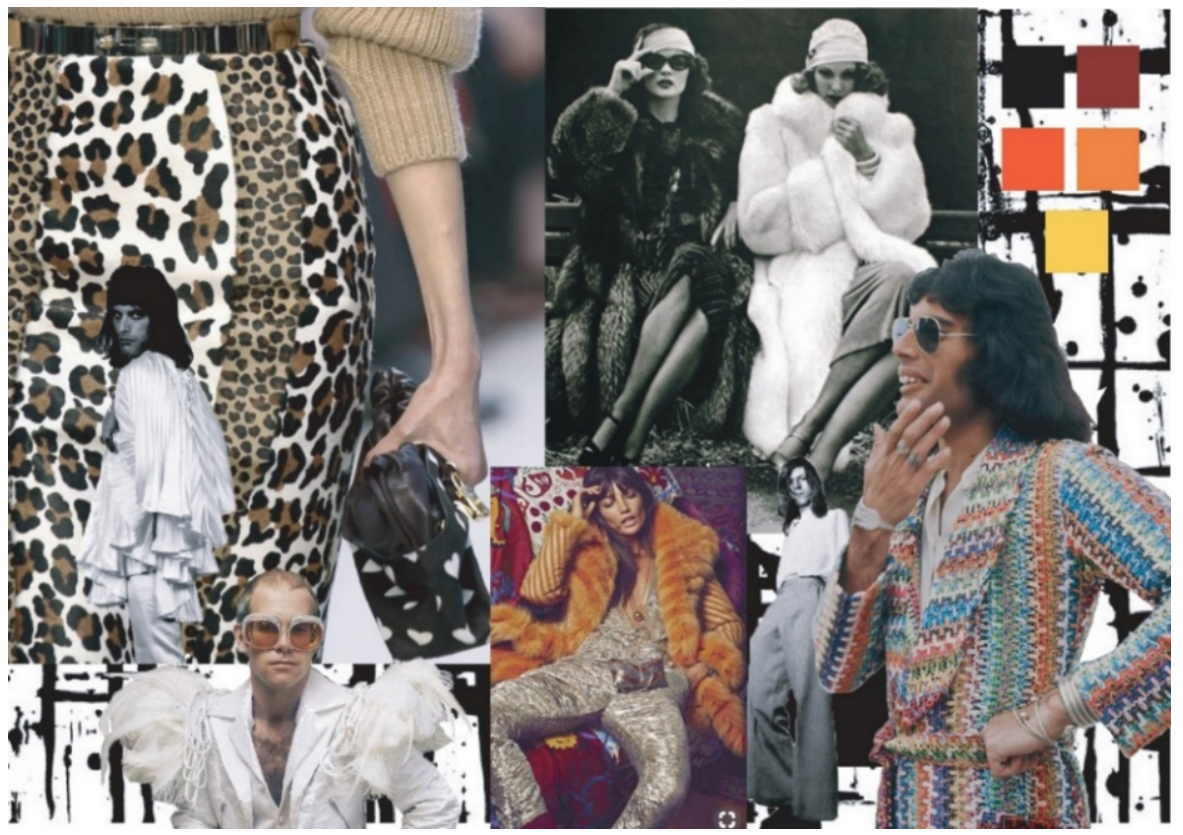

Figure 4. DosZeroTres moodboard panel.

Group \#2 designed DosZeroTres (Figure 4), a unisex prêt-à-porter Inclusive Fashion micro-collection, which takes into account wheelchair users. The collection was inspired by the paintings Number 203 (Luis Feito, 1960) and Diurnal Celebration (José Manuel 
Broto, 1983), which are preserved in the Museum-Foundation Juan March in Palma, and by the Disco movement of the 70s. DosZeroTres clothes are comfortable, bold, brightly coloured, and vibrant prints, designed for people with character, self-confidence, and a great sense of humour.

Two online questionnaires were used to collect data on the project, at the beginning and the end of the activity, to answer all research questions proposed.

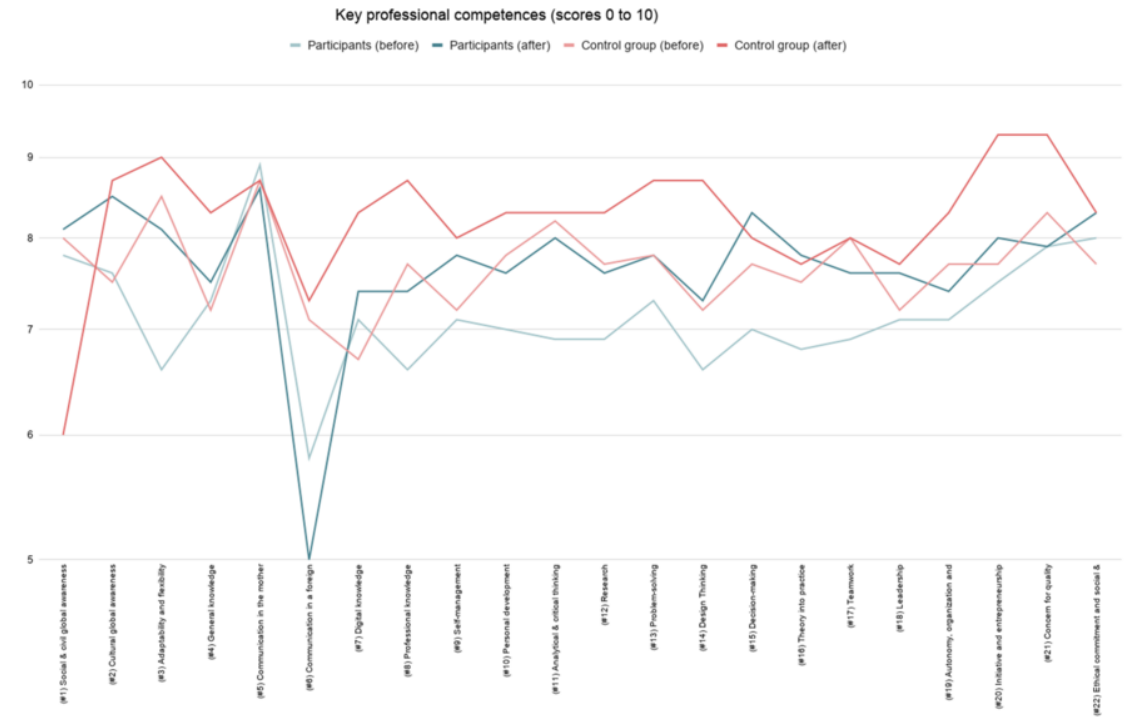

Figure 5. Participating students and control group key professional competences level, at the beginning and the end of the project (scored 0 to 10 ).

There was an improvement in the level of all key professional competences (Figure 5), except for communication (\#5). Table 1 and Table 2 expand the information provided in Figure 5. However, participating students did not report this improvement when assessing their key professional competences (Table 4).

Researchers detected insufficient autonomy skills while developing the project. Although the project was on schedule, participating students informed issues due to insufficient time management and stress management skills. Friction among team members was also reported and stalled teamwork. They also reported a lack of communication among participants in each group. Sadly enough, they stated that they would not have experienced such problems as reported, had the project been carried out individually.

The majority of participants identified the four professional profiles formulate by researchers, and they developed them during the co-design project (Table 3), especially participants in Group \#1. Three-fifths of participants also highlight cool-hunting (\#2) and tailored and made-to-measure costumes (\#13) as professional profile areas involved in the project. 
Table 1. Participating students and control group key professional competences level, at the beginning of the project.

\begin{tabular}{lccccc}
\hline \multicolumn{1}{c}{$\begin{array}{c}\text { Key competences } \\
\text { (scored 0 to 10) }\end{array}$} & $\begin{array}{c}\text { Group } \\
\text { \#1 }\end{array}$ & $\begin{array}{c}\text { Group } \\
\mathbf{2 2}\end{array}$ & Total & $\begin{array}{c}\text { Control } \\
\text { group }\end{array}$ & Total \\
\hline Social and civil global awareness (\#1) & 7.4 & 8.3 & 7.8 & 8.0 & 7.9 \\
\hline Cultural global awareness (\#2) & 7.6 & 7.7 & 7.6 & 7.5 & 7.6 \\
\hline Adaptability and flexibility (\#3) & 6.2 & 7.3 & 6.6 & 8.5 & 7.4 \\
\hline General knowledge (\#4) & 7.0 & 7.7 & 7.3 & 7.2 & 7.2 \\
\hline Communication in the mother language (\#5) & 8.8 & 9.0 & 8.9 & 8.7 & 8.8 \\
\hline Communication in a foreign language (\#6) & 5.4 & 6.3 & 5.8 & 7.1 & 6.3 \\
\hline Digital knowledge (\#7) & 6.8 & 7.7 & 7.1 & 6.7 & 6.9 \\
\hline Professional knowledge as specific body of & 6.8 & 6.3 & 6.6 & 7.7 & 7.1 \\
knowledge (\#8) & & & & & \\
\hline Self-management (\#9) & 7.2 & 7.0 & 7.1 & 7.2 & 7.1 \\
\hline Personal development (\#10) & 6.8 & 7.3 & 7.0 & 7.8 & 7.4 \\
\hline Analytical and critical thinking (\#11) & 6.8 & 7.0 & 6.9 & 8.2 & 7.4 \\
\hline Research (\#12) & 6.6 & 7.3 & 6.9 & 7.7 & 7.2 \\
\hline Problem-solving (\#13) & 7.4 & 7.0 & 7.3 & 7.8 & 7.5 \\
\hline Design Thinking (\#14) & 6.4 & 7.0 & 6.6 & 7.2 & 6.9 \\
\hline Decision-making (\#15) & 7.0 & 7.0 & 7.0 & 7.7 & 7.3 \\
\hline Theory into practice (\#16) & 6.8 & 6.7 & 6.8 & 7.5 & 7.1 \\
\hline Teamwork (\#17) & 6.2 & 8.0 & 6.9 & 8.0 & 7.4 \\
\hline Leadership (\#18) & 7.2 & 7.0 & 7.1 & 7.2 & 7.1 \\
\hline Autonomy, organization and planning (\#19) & 7.4 & 6.7 & 7.1 & 7.7 & 7.4 \\
\hline Initiative and entrepreneurship (\#20) & 7.6 & 7.3 & 7.5 & 7.7 & 7.6 \\
\hline Concern for quality (\#21). & 7.8 & 8.0 & 7.9 & 8.3 & 8.1 \\
\hline Ethical commitment and social \& & 8.0 & 8.0 & 8.0 & 7.7 & 7.9 \\
\hline environmental responsibility (\#22) & & & & & \\
\hline Total (N) & 5 & 3 & 8 & 6 & 14 \\
\hline
\end{tabular}

Table 2. Participating students and control group key professional competences level, at the end of the project.

\begin{tabular}{|c|c|c|c|c|c|}
\hline $\begin{array}{c}\text { Key competences } \\
(\text { scored } 0 \text { to 10) }\end{array}$ & $\begin{array}{c}\text { Group } \\
\# 1 \\
\end{array}$ & $\begin{array}{c}\text { Group } \\
\# 2 \\
\end{array}$ & Total & $\begin{array}{l}\text { Control } \\
\text { group }\end{array}$ & Total \\
\hline Social and civil global awareness (\#1) & 8.4 & 7.7 & 8.1 & 6.0 & 8.1 \\
\hline Cultural global awareness (\#2) & 8.8 & 8.0 & 8.5 & 8.7 & 8.4 \\
\hline Adaptability and flexibility (\#3) & 8.0 & 8.3 & 8.1 & 9.0 & 8.3 \\
\hline General knowledge (\#4) & 7.0 & 8.3 & 7.5 & 8.3 & 7.7 \\
\hline Communication in the mother language (\#5) & 8.4 & 9.0 & 8.6 & 8.7 & 8.6 \\
\hline Communication in a foreign language $(\# 6)$ & 5.4 & 6.7 & 5.0 & 7.3 & 6.3 \\
\hline Digital knowledge (\#7) & 7.0 & 8.0 & 7.4 & 8.3 & 7.6 \\
\hline $\begin{array}{l}\text { Professional knowledge as specific body of } \\
\text { knowledge (\#8) }\end{array}$ & 6.8 & 8.3 & 7.4 & 8.7 & 7.8 \\
\hline Self-management (\#9) & 7.2 & 8.7 & 7.8 & 8.0 & 7.8 \\
\hline Personal development (\#10) & 7.4 & 8.0 & 7.6 & 8.3 & 7.8 \\
\hline Analytical and critical thinking (\#11) & 7.8 & 8.3 & 8.0 & 8.3 & 8.1 \\
\hline Research (\#12) & 7.2 & 8.3 & 7.6 & 8.3 & 7.8 \\
\hline Problem-solving (\#13) & 7.2 & 8.7 & 7.8 & 8.7 & 8.0 \\
\hline Design Thinking (\#14) & 7.0 & 7.7 & 7.3 & 8.7 & 7.7 \\
\hline Decision-making (\#15) & 7.4 & 9.7 & 8.3 & 8.0 & 8.1 \\
\hline Theory into practice ( $\# 16)$ & 7.4 & 8.6 & 7.8 & 7.7 & 7.7 \\
\hline Teamwork (\#17) & 6.8 & 9.0 & 7.6 & 8.0 & 7.8 \\
\hline Leadership (\#18) & 7.6 & 7.7 & 7.6 & 7.7 & 7.7 \\
\hline Autonomy, organization and planning (\#19) & 7.4 & 7.3 & 7.4 & 8.3 & 7.7 \\
\hline Initiative and entrepreneurship (\#20) & 7.8 & 8.3 & 8.0 & 9.3 & 8.3 \\
\hline Concern for quality (\#21). & 7.4 & 8.7 & 7.9 & 9.3 & 8.3 \\
\hline $\begin{array}{l}\text { Ethical commitment and social \& } \\
\text { environmental responsibility (\#22) }\end{array}$ & 8.2 & 8.3 & 8.3 & 8.3 & 8.3 \\
\hline $\operatorname{Total}(\mathrm{N})$ & 5 & 3 & 8 & 4 & 12 \\
\hline
\end{tabular}


Table 3. Participating students' results for professional profile areas involved (average).

\begin{tabular}{|c|c|c|c|}
\hline $\begin{array}{l}\text { Professional profile areas } \\
\end{array}$ & Group \#1 & Group \#2 & Total \\
\hline \multicolumn{4}{|l|}{$\begin{array}{l}\text { a) Main professional profile areas (formulated by } \\
\text { researchers) }\end{array}$} \\
\hline Fashion and clothing design (\#1) & 80.0 & 33.3 & 75.0 \\
\hline Styling (\#3) & 60.0 & 66.7 & 62.5 \\
\hline Figurines and fashion illustration (\#12) & 40.0 & 33.3 & 37.5 \\
\hline Research (\#15a) & 80.0 & 33.3 & 62.5 \\
\hline \multicolumn{4}{|l|}{$\begin{array}{l}\text { b) Secondary professional profile areas (formulated by } \\
\text { researchers) }\end{array}$} \\
\hline Fashion accessories design (\#6) & 0.0 & 0.0 & 0.0 \\
\hline Textile design (\#7) & 40.0 & 0.0 & 25.0 \\
\hline Teaching (\#15b) & 20.0 & 0.0 & 12.5 \\
\hline \multicolumn{4}{|l|}{ b) Tertiary professional profile areas (identified by students) } \\
\hline Cool-hunting (\#2) & 60.0 & 66.7 & 62.5 \\
\hline Art Direction (\#4) & 20.0 & 100.0 & 50.0 \\
\hline Costumes for theatre and cinema (\#5) & 20.0 & 33.3 & 25.0 \\
\hline Corporate image design and management (\#8) & 0.0 & 33.3 & 12.5 \\
\hline Customize or corporate design (\#10) & 40.0 & 33.3 & 37.5 \\
\hline Fashion and clothing design for specific activities (\#11) & 80.0 & 33.3 & 63.5 \\
\hline Tailored and made-to-measure costumes (\#13) & 60.0 & 66.7 & 62.5 \\
\hline $\begin{array}{l}\text { Design, research and development of new concepts, materials, } \\
\text { applications and products (\#14) }\end{array}$ & 60.0 & 66.7 & 50.0 \\
\hline Total $(\mathrm{N})$ & 5 & 5 & 8 \\
\hline
\end{tabular}

Table 4. Participating students' results for key professional competences to be acquired, developed, and/or consolidated (average).

\begin{tabular}{|c|c|c|c|}
\hline Key professional competences & Group \#1 & Group \#2 & Total \\
\hline \multicolumn{4}{|l|}{$\begin{array}{l}\text { a) Main key professional competences (formulated by } \\
\text { researchers) }\end{array}$} \\
\hline Research (\#12) & 80.0 & 100.0 & 87.5 \\
\hline Problem-solving (\#13) & 60.0 & 66.7 & 62.5 \\
\hline Design Thinking (\#14) & 20.0 & 66.7 & 37.5 \\
\hline Decision-making (\#15) & 60.0 & 66.7 & 62.5 \\
\hline Theory into practice (\#16) & 20.0 & 0.0 & 12.5 \\
\hline Teamwork (\#17) & 60.0 & 66.7 & 62.5 \\
\hline \multicolumn{4}{|l|}{$\begin{array}{l}\text { b) Secondary key professional competences (formulated by } \\
\text { researchers) }\end{array}$} \\
\hline Social and civil global awareness (\#1) & 100.0 & $66-7$ & 87.5 \\
\hline Communication in the mother language $(\# 5)$ & 40.0 & 66.7 & 50.0 \\
\hline Professional knowledge as specific body of knowledge (\#8) & 20.0 & 33.0 & 25.0 \\
\hline Self-management $(\# 9)$ & 40.0 & 33.0 & 37.5 \\
\hline Leadership (\#18) & 20.0 & 33.0 & 35.0 \\
\hline Autonomy, organization and planning (\#19) & 80.0 & 0.0 & 50.0 \\
\hline Initiative and entrepreneurship (\#20) & 20.0 & 33.0 & 12.5 \\
\hline Concern for quality $(\# 21)$ & 0.0 & 33.0 & 12.5 \\
\hline $\begin{array}{l}\text { Ethical commitment and social \& environmental responsibility } \\
(\# 22)\end{array}$ & 20.0 & 0.0 & 12.5 \\
\hline \multicolumn{4}{|l|}{$\begin{array}{l}\text { b) Tertiary key professional competences (identified by } \\
\text { students) }\end{array}$} \\
\hline Cultural global awareness (\#2) & 40.0 & 66.7 & 50.0 \\
\hline Adaptability and flexibility (\#3) & 60.0 & 33.3 & 50.0 \\
\hline General knowledge (\#4) & 40.0 & 66.7 & 50.0 \\
\hline Digital knowledge (\#7) & 20.0 & 66.7 & 37.5 \\
\hline Personal development (\#10) & 80.0 & 33.3 & 62.5 \\
\hline Analytical and critical thinking (\#11) & 40.0 & 33.3 & 37.5 \\
\hline Total $(\mathrm{N})$ & 5 & 5 & 8 \\
\hline
\end{tabular}

Although the professional profile areas involved in the project were the same for both groups, only the majority of a participant in Group \#1 identifies them. 
During the co-design project, EASDIB researchers promoted a learning community where participants were students and teachers at the same time. However, only one participant was able to identify teaching (\#15b) ad a professional profile area involved in the project.

Not all students identified the main competences selected by EASDIB researchers (Table 4). Students did not perceive design thinking (\#14) and theory into practice (\#16) as key professional competences; however, they highlighted these competences when writing down a micro-story of the experience.

Table 5. Participating students' results for Fashion Design competences to be acquired, developed, and/or consolidated (mode).

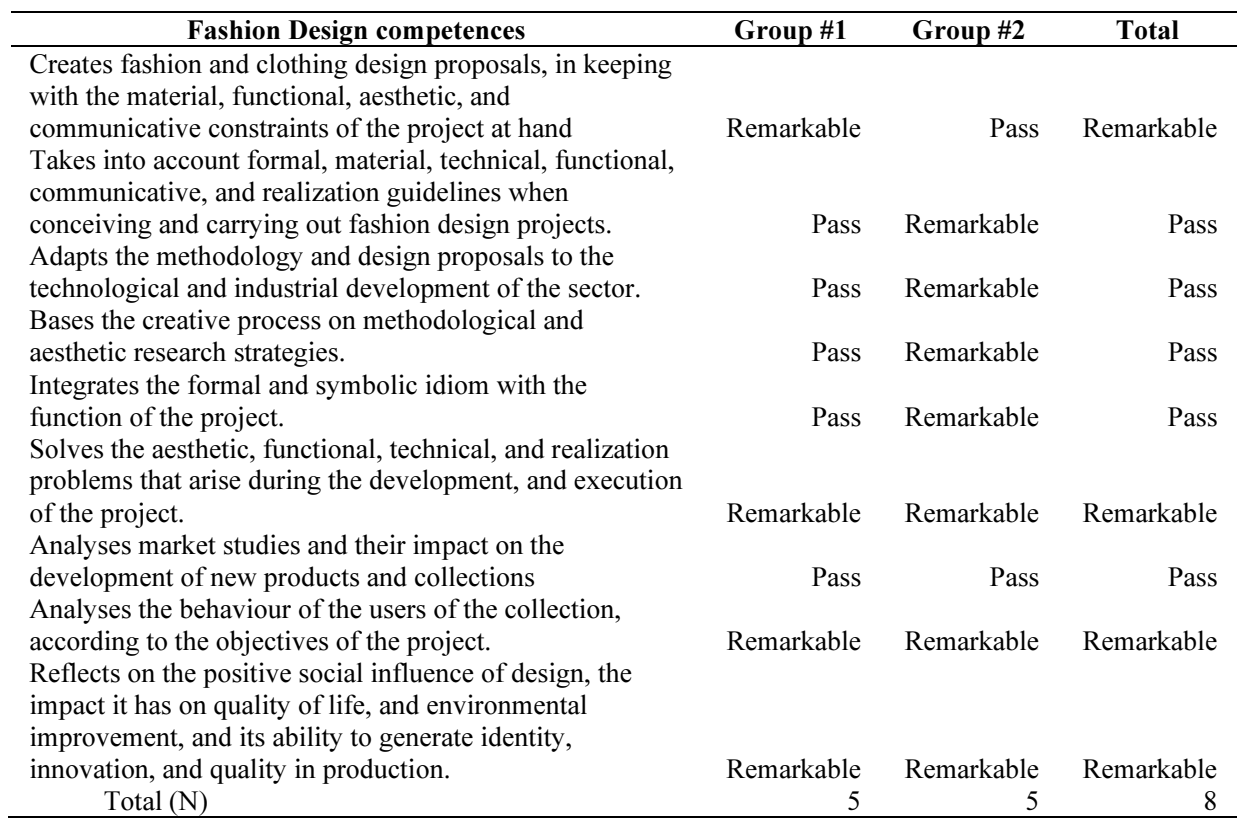

Participants scored mainly as a pass for Fashion Design competences to be acquires developed, and/or consolidated when developing the activity mainly (Table 5). However, participants scored learning outcomes mainly as remarkable (Table 6).

Table 6. Participating students' results for learning outcomes to be achieved (mode)

\begin{tabular}{|c|c|c|c|}
\hline Learning outcomes & Group \#1 & Group \#2 & Total \\
\hline $\begin{array}{l}\text { Shows design as a key factor for success for organizations. } \\
\text { Conceives, develops, and communicates a trans- } \\
\text { disciplinary co-design project, under the principle of } \\
\text { Universal Design. }\end{array}$ & Remarkable & Remarkable & Remarkable \\
\hline $\begin{array}{l}\text { Strengthens links among the community around a } \\
\text { teaching-learning project through design. } \\
\text { Develops a teaching-learning activity that enhances key } \\
\text { professional competences, and competences related to }\end{array}$ & Remarkable & Remarkable & Remarkable \\
\hline Fashion Design studies. & Remarkable & Remarkable & Remarkable \\
\hline $\begin{array}{l}\text { Sensitizes on a specific social topic and enhances reflexive } \\
\text { practice. }\end{array}$ & Remarkable & Remarkable & Remarkable \\
\hline $\begin{array}{l}\text { Participates in your training process and creates a culture } \\
\text { of life-long self-learning. }\end{array}$ & Remarkable & Remarkable & Remarkable \\
\hline $\operatorname{Total}(\mathrm{N})$ & 5 & 5 & 8 \\
\hline
\end{tabular}


Half of the participants reported learning new things as the best issue from experience. On the other hand, three-fifths of participants stated unforeseen problems as the worst issues from experience. Sadly, only one-fourth highlighted teamwork (as the best), and researchers believed that this answer is closely related to group conflict (as the worst).

It is about learning, and one-third stated analysing and understanding users' needs as the main learnings from experience. One-fifth also stated problem-solving, pattern making, teamwork, and market research as important learnings. On the other hand, anticipated planning, following design process, and communication were the learning less scored. However, three-fifth of participants do not seek to repeat the experience.

Group \#1 perception on project relevance for further academic pursuits scored 7.2, relevance for future career paths scored 7.2, and the overall activity scored 7.2. On the other hand, Group \#2 perception of project relevance for further academic pursuits scored 7.3, relevance for future career paths scored 6.0, and the overall activity scored 5.7. Finally, participants' perception of project relevance for further academic pursuits scored 7.3, relevance for future career paths scored 6.8, and the overall activity scored 6.6.

Interestingly, a low score in relevance for future career paths, as Inclusive Fashion has a potential market of more than one billion people in the world $(1.4 \%$ of the world population), according to the World Health Organization [5], and almost 4 million people in Spain (8.6\% of the Spanish population), according to the Spanish Committee of Representatives of Persons with Disabilities [6].

In any case, enhancing communication (\#5) is the key to success, as it is the most important tool to improve results in future co-design projects, not only about the main key professional competences prior selected, but especially about professional profile areas involved (communication before, during, and after the activity).

\section{Conclusion}

This article was aimed at answering six research questions:

- Research question \#1: Is there any difference in students' perception about acquiring, developing, and/or consolidating key professional competences, at the beginning and the end of the activity?

- Research question \#2: Is there any difference in students' perception between the participating group and the control group?

- Research question \#3: Do participating students identify professional profile areas involved in the project?

- Research question \#4: Do participating students identify key professional competences selected by researchers?

- Research question \#5: Do participating students acquire, develop, and/or consolidate competences related to BA in Fashion Design studies?

- Research question \#6: Do participating students achieve learning outcomes selected by researchers?

To answer these research questions, a Design for All experience was developed at the Balearic School of Art and Design, to introduce BA in Fashion Design students to the fascinating world of Inclusive Fashion.

During the first semester of the academic year 2019-2020, participants conceived, developed, and communicated a trans-disciplinary co-design project; it was designed 
under the principle of Universal Design (Figures 6 to 9). The «Museum and Inclusive Fashion» project was developed, questionnaires were taken to collect data, and results did answer these research questions.

The response to Research question \#1 was a «Yes». There was a difference in the level of students' perception about acquiring, developing, and/or consolidating key professional competences, at the beginning and the end of the activity, except for communication (\#5).

Either it was the response to Research question \#2. There was a slight difference in students' perception between the participating group and the control group.
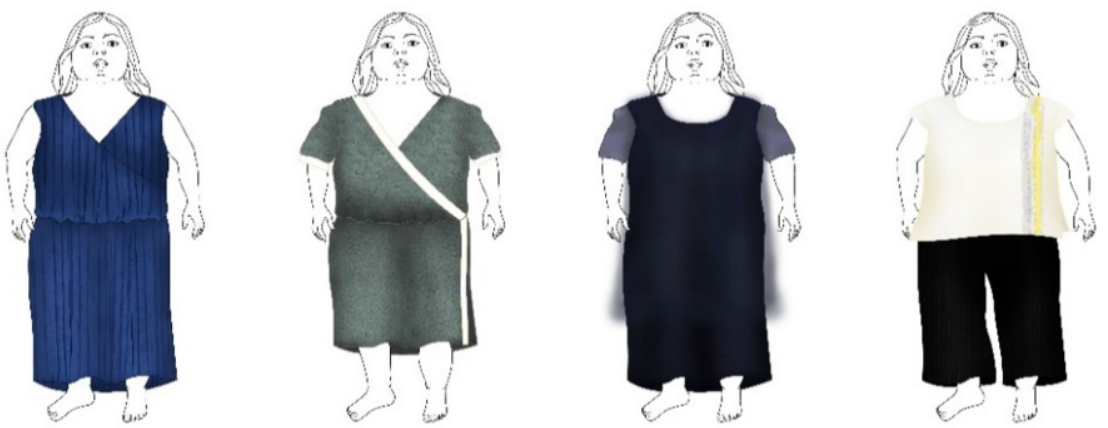

Figure 6. Blue View fashion illustrations.

The response to Research question \#3 was certainly a «No». Participants did not identify professional profile areas involved in the project selected by EASDIB researchers, especially the teaching area. When asked, students took it for granted, and/or there was a lack of communication.

The response to Research question \#4 was also a «No». Participants did not identify all main competences selected by EASDIB researchers. Even though Teamworking (\#17) was the core of the co-design project.
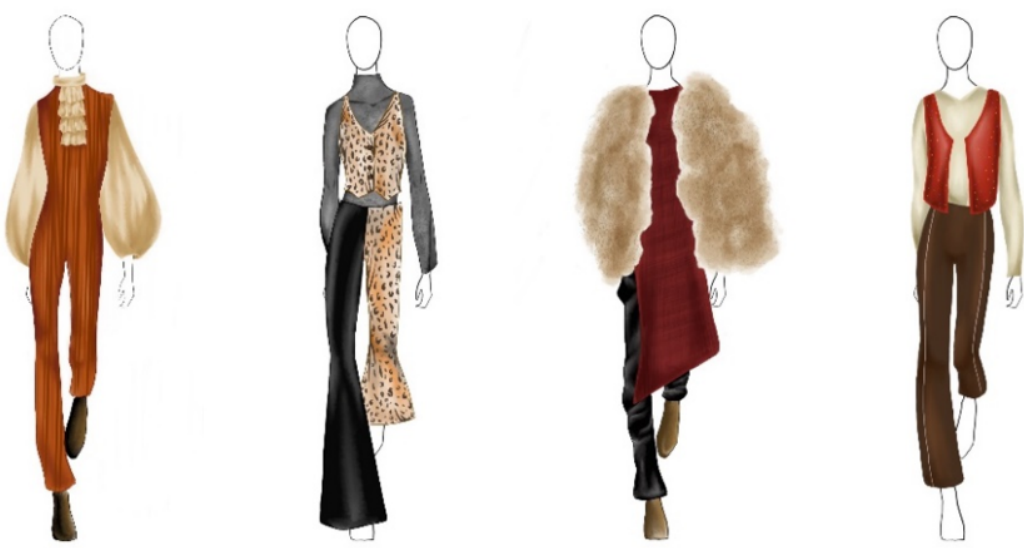

Figure 7. DosZeroTres fashion illustrations. 
The response to Research question \#5 was a «Yes». Participants acquired, developed, and/or consolidated competences related to BA in Fashion Design studies, although they scored almost all competences as «Pass».

Finally, the response to Research question \#6 was a «Yes». Participants achieved learning out-comes selected by researchers. They scored almost all learning outcomes as «Remarkable».

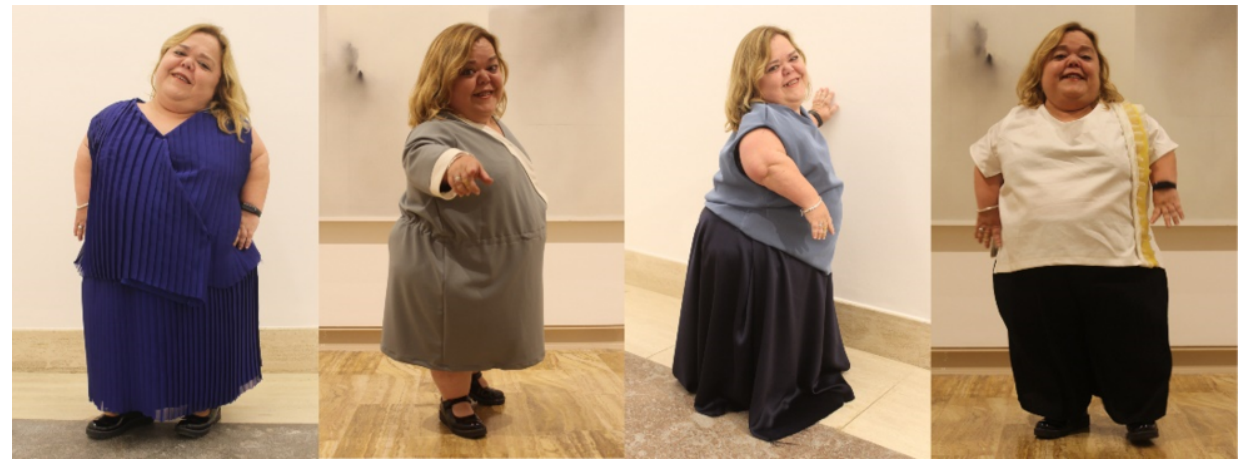

Figure 8. Blue View shooting at the Foundation-Museum Juan March in Mallorca.

Despite the mixed results, EASDIB researchers are convinced that Inclusive Fashion, project-based learning, and Design for All, allow professors a greater assessment of what a design student is expected to know, understand or be able to do when studying BA in Fashion Design at the EASDIB. Again, it is all about students' perception, not about the work professors have done. It is all about communication, professors' and students' better communication skills.

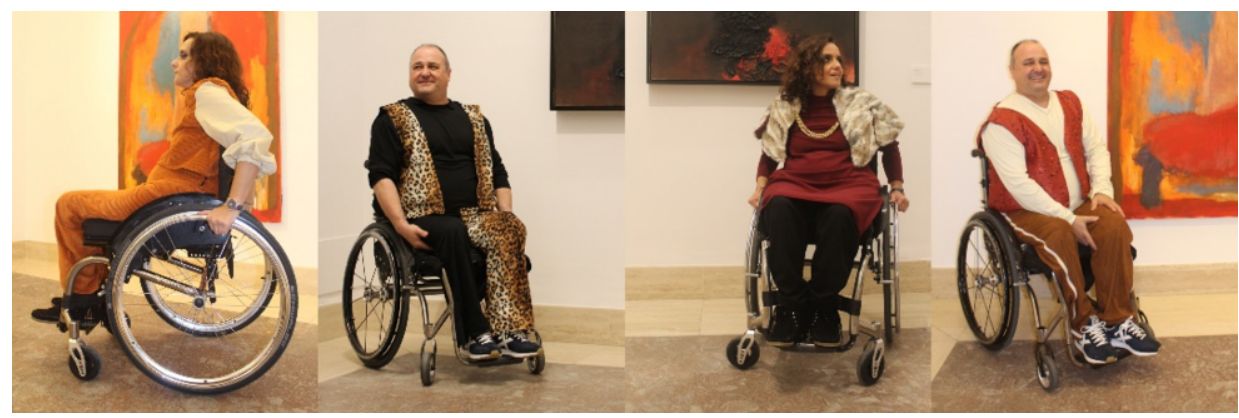

Figure 9. DosZeroTres shooting at the Foundation-Museum Juan March in Mallorca.

To sum up, Design for All is aimed to promote the autonomy and independence of the users. It implies projecting from the beginning to the end of the design process based on inclusion. Although Standard Fashion does not include Inclusive Fashion; on the contrary, Inclusive Fashion use to be opened to Standard Fashion. 
At the end of the project, students and researchers developed ten basic tips for Inclusive Fashion Design.

- Think about the users of the product and observe them. Pay close attention to their gender, age range, abilities, personal situation, and needs. In case of doubt, ask everyone: users, their caregivers, and their families. In case of doubt, ask again. Always check the final product with the users.

- Consider the four dimensions of design when creating Inclusive Fashion: a/ Functional dimension: a degree of mobility, prosthesis, diaper or probe use; b/ Aesthetic dimension: volume, silhouette, movement; colour palette; material chart, fabric prints, textures, and combinations; c/ Social dimension: work, leisure, sport, casual, and formal clothes; and $\mathrm{d} /$ Subjective dimension: personality, mood, self-esteem, health.

- Create clothes that are easy to put on and take off. Promote personal autonomy and user independence when dressing.

- Consider the different parts of a person's body. Adapt patterns to user's needs. Make neck, sleeves, chest, abdomen, and baggy legs wider.

- Choose natural, light, comfortable, elastic, breathable, absorbent, waterproof, and antibacterial fabrics. Avoid chemicals in dyes and textile finishing. Try sewing with natural threads.

- Choose flat seams and exterior seams to avoid chafing. Control tissue volume to prevent wrinkles in clothing.

- Use T-shirts, blouses, shirts, sweaters, jackets, and coats to cover the upper part of the body. Use specific opening systems, such as standard or crossed back closure, open yoke, without the back, without the back but with open neck.

- Use skirts and trousers to cover the lower part of the body. Replace buttons, snaps, zippers, and hooks with easy hooking systems such as elastics, magnets, or Velcro.

- Try to make customization becoming to the users. Look for inclusive solutions.

- Use your imagination. Make the most of your own experience. Look for creative solutions. Design for All people or, at least, create a final product that can be used by a significant number of users.

This list included research [7] [8], celebrities' experience [9] [10] [11], students' experience, and models' experience.

As members of a school community, students must learn about other realities that differ from their everyday environment. What is more, as members of a school of design, students must be aware of an important prospective market niche and expand their fields of action that must include Design for All.

It is impossible to cover all possible types of disability (physical, intellectual/cognitive, neuropsychiatric, attitudinal, and communication) that exist, but Design for All proposals try to do their best to into account different abilities. In any case, human diversity is the key concept to approach user-centred design in the twenty-first century.

\section{Acknowledgments}

The «Museum and Inclusive Fashion» project was supported by third year fashion design EASDIB students: Daniela A. Cardona, Selene Cifre, Anabel Collado, Marta Duran, Francesca Fernández de Heredia, Lis Nadia Mir, Andrea Mollá and Laia Sastre. For their availability and priceless cooperation, our special thanks go to our models: Antonio 
Azorín, Maria del Carmen Madrid, and Fabiola Moro. Also, the assistance provided by Víctor Palacios and Assumpta Capellà was greatly appreciated.

The «Museum and Inclusive Fashion» project was part of an ongoing academic research project funded by the Balearic Government (2017-2020). This article reflects the views only of the authors, and the Balearic Government cannot be held responsible for any use which may be made of the information contained therein.

\section{References}

[1] UN Convention on the Rights of Persons with Disabilities, adopted on 2006, 13th December, https://www.un.org/development/desa/disabilities/convention-on-the-rights-of-persons-withdisabilities.html.

[2] Moving for a Good Mood, Fit and Sit S.L., Mataró (Barcelona, Spain), http://movingmood.com/.

[3] Museum-Foundation Juan March in Palma, https://www.march.es/arte/palma/?1=2.

[4] M.P. Rovira, 8- New Opportunities, new Competences, new Challenges. Learning through Civic Engagement at the Balearic School of Art and Design, Diálogos com a Arte. Revista de arte, cultura e educação 6 (2016), 95-129, http://media.wix.com/ugd/6d6107 422ab60394f44b96bcd9d4664d6b129e.pdf.

[5] World Health Organization, World report on disability, World Health Organization \& The World Bank, Geneva (Switzerland), 2011, https://apps.who.int/iris/bitstream/handle/10665/44575/9789240685215 eng.pdf? sequence $=1 \&$ isAllowed $=y \& u a=1$.

[6] The Spanish Committee of Representatives of Persons with Disabilities (CERMI), https://www.cermi.es/en/cermi.

[7] G. Sorondo, Autonomía e inclusión en el vestir. Indumentaria Adaptada, Departamento Imprenta del INTI-Tecnologías para la Salud y Discapacidad. San Martín (Buenos Aires, Argentina), 2015, http://ciapat.org/biblioteca/pdf/1217Autonomia_e_Inclusi\%C3\%B3n_en_el_Vestir_Indumentaria_Adaptada.pdf.

[8] M. Scheier, How adaptative clothing empowers people with disabilities (13:41 minutes), TED@Tommy Hilfiger, Amsterdam (The Netherlands), November 2017, https://www.ted.com/talks/ mindy_scheier_how_adaptive_clothing_empowers_people_with_disabilities.

[9] S. Burke, https://www.sinead-burke.com/, https://www.instagram.com/thesineadburke/, https://www.facebook.com/TheSineadBurke/, https://twitter.com/thesineadburke?lang=es.

[10] A. Philips, https://www.instagram.com/aaron_ philip/.

[11] A. Graham, https://www.instagram.com/ashleygraham/?hl=en, https://www.facebook.com/ theashleygraham/, https://www.youtube.com/channel/UCGp6FxRC5mcRvoPz71NMpHg. 